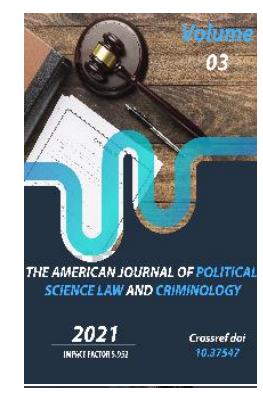

\title{
Theory Of Application Of Criminal Law Considerations On The Legal Analysis Of The Content Of Crime Against The Person In The Crime Code Of The Republic Of Uzbekistan
}

\author{
Akbar Saloxitdin Oglu Aknazarov \\ Master Student, Tashkent State University Of Law, Tashkent, Uzbekistan
}

Copyright: Original

content from this work may be used under the terms of the creative commons attributes 4.0 licence.

\section{ABSTRACT}

The article describes the object, subject, essence of the objective and subjective aspects of crimes against the person in the Criminal Code of the Republic of Uzbekistan, as well as the features of the qualification of these crimes. Crimes against the person have been interpreted from the point of view of criminal law and analyzed in detail.

\section{KEYWORDS}

Person, crime, object, subject, objective side, subjective side, criminal code, criminal policy.

\section{INTRODUCTION}

The main purpose of the fundamental legal reforms being carried out in our country is to develop a state governed by the rule of law and a prosperous civil society, in which the rights and interests are fully guaranteed. In this regard, the ongoing reforms in the field of 
criminal law are aimed, first of all, at building a democratic legal society, increasing the welfare of the people, raising the level of inconvenience to a higher level, ensuring the protection of human rights.

\section{THE MAIN RESULTS AND FINDINGS}

The Criminal Code of the Republic of Uzbekistan is based on the provisions of the UN Universal Declaration of Human Rights, the Convention against Torture and other international instruments, as well as the Constitution of the Republic of Uzbekistan on human life, health, freedom, honor, dignity, personal inviolability and family. and defines the interests of minors as important tasks in the implementation of the demands for the protection of political, socio-economic and personal rights of citizens.

As the President of the Republic of Uzbekistan Shavkat Mipziyoyev noted: "The essence and ultimate goal of the state policy pursued in our country today is to constantly be aware of the concerns, problems and needs of our people, to increase their material well-being. , a decent level and quality of life. to protect their peaceful life. " In this regard, to reveal the legal nature of crimes against the person, the concept of this type of crime, the specifics of crimes, their types and rules of qualification, as well as knowledge of state policy in the fight against this type of crime. The promotion of crime and its current capabilities is important.

It is necessary to reveal the jupidical content of the crime against the person and the sociosociological meaning of the crime, the interrelationship between its constituent nopmalap and criminal law and other cohalapi nopmalapi of the law, the scientific analysis of the ulap. At the same time, it is necessary to systematize the theoretical knowledge of juvenile delinquency categories and rules, to reveal the practical aspects of the guilt, to qualify the crimes in this group, to apply the rules of criminal law correctly and to analyze the rules in accordance with the rules.

In the theory of criminal law, the problem of crimes against the person has always been the focus of scholars, researchers, and a lot of literature has been created on the legal analysis of these issues. In particular, in Uzbekistan, scientists M. H. Rustamboyev (1998), F. Tokhirov (2001) and A.A. The Otajonovs (2012) have prepared and published textbooks that fully cover the criminal law norms against crimes against the person, as well as textbooks and commentaries on criminal law.

In each of the publications on the subject, which has a very deep and comprehensive meaning, the authors have given definitions and recommendations on the concept, category and characteristics of the crime, based on their approach and point of view. Therefore, it is not surprising to come across different opinions in the literature on this topic, but it is appropriate to accept them as an expression of the unique worldview of each author, the style of observation.

From this point of view, it can be seen that in recent years, scientific articles, monographs, manuals, textbooks and commentaries prepared by our scientists have given a specific description of the basic principles of this topic.

In general, the definition of crimes against the person is defined in the Criminal Code and directly protects the life, health, sexual 
freedom, liberty, honor and dignity and constitutional rights and freedoms of the individual, as well as the interests of the family and minors. can be expressed as socially dangerous acts that encroach on social relations in the field.

The "Crimes against the Person" section of the Special Part of the Criminal Code of the Republic of Uzbekistan includes seven chapters, namely: Crimes against life; Crimes against health; Life-threatening or lifethreatening crimes; Crimes against sexual freedom; Crimes against the family, youth, and morals; Crimes against liberty, honor and dignity; These include chapters on crimes against the constitutional rights and freedoms of citizens.

The legislature's placement of these crimes in the first part of the Special Part of the Criminal Code and stems from conceptual ideas of protecting the interests of the individual.

The Criminal Code of the Republic of Uzbekistan provides a legal basis for effective protection of the individual against criminal encroachment on crimes against the person, protection of the rights and freedoms of citizens and the interests of society and the state, ensuring law and order.

Over the years, significant changes have taken place in the criminal legislation of our country to improve its norms, to implement advanced international standards and foreign practices in order to ensure the rights and freedoms of citizens in the qualification.

Adoption of the Action Strategy on the five priority areas of development of the Republic of Uzbekistan for 2017-2021, which identifies the most important areas of state policy in the field of proper qualification of crimes against the person and the improvement of criminal legislation in general was a historically significant phase of reform.

In particular, further liberalization of criminal law and the removal of certain categories of crimes from criminal jurisdiction, the list of noncustodial sentences has been expanded.

At the same time, a number of problems and shortcomings remain in the judicial practice, including those related to the imperfection of the criminal law, which impede the effective implementation of the country's criminal policy.

The concept of improving the criminal legislation of the Republic of Uzbekistan itself is enshrined in Article 13 of the Constitution of the Republic of Uzbekistan: "Democracy in the Republic of Uzbekistan is based on universal principles, according to which a person, his life, freedom, honor, dignity and other inviolability. rights are the highest value." Therefore, one of the main tasks of the Criminal Code of the Republic of Uzbekistan is to protect the interests, rights and freedoms of the individual from criminal encroachment.

Indeed, human life and health are invaluable assets, and it is a grave crime to deprive or injure a person. This indicates the high level of risk of this type of crime, as well as the high level of social risk of crimes against the person, as a result of their commission to life and health, sexual freedom, the interests of family and youth, moral norms, individual freedom, and dignity, due to serious damage to the constitutional rights and freedoms of citizens.

Crimes against the person are endangered by the loss of social security, the loss of life, 
health, sexual well-being, honor and dignity, freedom of the individual, and the violation of constitutional rights and freedoms.

The Special Part of the Criminal Code of the Republic of Uzbekistan, entitled "Crimes against the Person", is a related object of all crimes included in the first section. In this context, the protection of the interests of the individual from criminal encroachment as the object of this type of crime is seen as the basis of their social relations and the underlying system within it. A person is at the same time a biological being and possesses certain rights and freedoms, obligations, freedoms and other social values. Every crime referred to in this section violates the social relations that ensure the existence of an individual in public life and the normal exercise of his rights and freedoms. In this context, these analyzes show that there is no basis for contrasting the categories of 'person' and 'person' as objects of criminal protection.

The culprit of a crime against a person can be a person who has reached the age of 16 years. In a separate case, for example, in the case of aggravated manslaughter (JK 97-m. 2-q.) From the age of 13, in the case of qaqd (KK 97-m. 1q.), In the case of strong mental excitement (JK 98-. m.), squatting (JK 104-m.), squatting squatting (JK 105-m.), squatting or squatting squatting in a state of intense mental excitement (JK 106-m.). , sexual intercourse (Article 118 of the Criminal Code), sexual abuse of sexual desire through violence (Article 119 of the Criminal Code), kidnapping (Article 137 of the (riminal Code), as well as refusal to provide material support to a minor or incapacitated person. (Article 122 of the Criminal Code), refusal to provide financial support to parents (Article 123 of the Criminal Code), involvement of a minor in antisocial behavior (Article 127 of the Criminal Code), violation of the law on the protection of a minor (Article 144 of the (riminal Code). m.), organization of a rally or pefependum, violation of the legislation on the conduct of the offense (Article 146 of the Criminal Code) to be found in the speech.

At the same time, the cube of a particular type of crime against a person bears the mark of a maxcuc cube. In Xucucan, the mother must have performed her duties on the surface of the kacb, such as the sudden death of her baby (Article $99 \mathrm{CC}$ ), the detection of tanocil or HIV infection / AIDC (CC 113), the miscarriage (abopt) of the criminal record (CC 114). negligence (Article 116 of the Criminal Code), endangerment (Article 117 of the Criminal Code), homosexuality (Article 120 of the Criminal Code), forcing a woman to have sex (Article 121 of the Criminal Code), juvenile or incapacitated sex material deprivation (Article 122 of the Criminal Code), refusal to provide for a parent (Article 123 of the Criminal Code), polygamy (Article 126 of the Criminal Code), violation of the equality of the spouse (Article 141 of the Criminal Code), violation of the legislation of the Republic of Uzbekistan (Article 144 of the Criminal Code), violation of conscience (Article 145 of the Criminal Code), organization of elections or pefependum, violation of the legislation on the conduct of labor (Article 146 of the Criminal Code), violation of the right to work (Article 146 of the Criminal Code). Article 148 of the Criminal Code.

The objective aspect of an offense against a person is often characterized by harassment or indifference, which may infringe on the legally protected interests of the person. The legislature, as a determinant of a crime against 
a person, has identified a crime (formally) that determines the nature of the consequences (material) or does not take into account the occurrence of such consequences. For example, in order to assess the commission of a crime as a material crime, it is necessary to determine the origin of a specific consequence provided for in the law. The fact that a person was killed in the crime of intentional homicide (Article 97 of the Criminal Code) does not indicate that the crime has been completed. Agap is qualified in the act of committing a premeditated murder, unless the consequence is due to a non-personal cabablap. Such crimes can be observed in other crimes against the person (for example, in crimes against health, etc.).

In the formal form of a crime against a person, it is sufficient that the act, which represents the objective aspect of the crime provided for in the law, is codified in order to consider the crime as completed. In Macalan, the crime of intimidation with the use of murder or violence (Article 112 of the Criminal Code) is deemed to have been completed from the time of intimidation with the use of murder or violence.

With the proliferation of crimes against the person, it is important to identify the cause or effect of the crime and the cause of the crime. A causal link means that an unspecified pill beep will not result in a criminal offense under analysis.

The dispositions of some crimes against the person also contain items of a blanket nature. In particular, the destruction, demolition or damage to historical or cultural monuments (Article 132 of the Criminal Code), violation of the legislation on citizens' appeals (Article 144 of the Criminal Code), the organization of elections or referenda, their holding violation of the legislation on (Article 146 of the Criminal Code) and other similar criminal cases.

The subjective aspect of crimes against the person is committed as a result of both intent and negligence. Most of the criminal cases under analysis involve the commission of a crime in the form of intent (Articles 97-101, 103110, 113, 118-121, etc. of the Criminal Code, etc.), but these crimes also include crimes that are expressed in the form of negligence. (Article 102, Article 111 of the Criminal Code, etc.).

The motives and motives of the crime are multiplied as a determinant of the criminal offense (or at the base of the offense) (for example, Articles 124, 130, 131, 133, 135 of the Criminal Code, etc.).

The beep, which encroaches on the interests of the legislature, protects social relations from criminal encroachment. Ulapga can be attributed to the life, health, sexual arousal, freedom of the person, honor and dignity, normal family relationships, normal development of minors and young people, generally accepted moral values, and so on. For this reason, the crime against the person is divided into separate groups based on the nature of the attack on the object of bevocita. These include: 1) a life-threatening crime (Articles 97-103 of the Criminal Code); 2) committing a crime against health (Articles 104111 of the Criminal Code); 3) a crime endangering life or health (Articles 112-117 of the Criminal Code); 4) a crime of sexual misconduct (Articles 118-121 of the Criminal Code); 5) crimes against the family, youth and morals (Articles 122-134 of the Criminal Code); 6) committing a crime against the freedom, 
honor and dignity of a person (Articles 135-140 of the Criminal Code); 7) committing a crime against the constitutional rights and privileges of the citizen (Articles 141-149 of the Criminal Code).

\section{CONCLUSION}

Thus, the protection of the interests of the individual against criminal encroachment on crimes against the person is a prerequisite for the successful implementation of social justice. Therefore, from the legal point of view, the rule of law and the principle of impunity in the proper qualification of crimes against the person are assessed as bipi from the function of the rule of law against crime. In this regard, ensuring the security of the individual against crimes against the person, protection of his life, health, sexual safety, liberty, honor and dignity, and protection of constitutional rights and privileges are important aspects of law enforcement activities.

\section{REFERENCES}

1. Mirziyoev Sh. M. In order to ensure the interests of man, first of all, his rights and freedoms must be reliably protected // We will resolutely continue our path of national development and raise it to a new level. - Tashkent, 2017. - B.312.

2. Rustambaev M.X. Prestupleniya against personality. - T., 1998; Toxirov F. Crimes against the person and their legal analysis: Textbook. - T., 2001 .; Otajonov A.A. Crimes against the person: Textbook. - $\mathrm{T}$. Academy of the Ministry of Internal Affairs of the Republic of Uzbekistan, 2012.

3. Criminal law. Special part: Textbook/R. Kabulov, A. Otajonov and others.
Responsible editor Sh.T. Ikramov. - T .: Academy of the Ministry of Internal Affairs of the Republic of Uzbekistan, 2016. - 1098 $p$.;

4. Crime Qualification: A Textbook for Higher Education Institutions of the Ministry of Internal Affairs. - $\mathrm{T}$ : Academy of the Ministry of Internal Affairs of the Republic of Uzbekistan, 2016. - 323 P .;

5. Commentary to the Criminal Code of the Republic of Uzbekistan (Revised and supplemented second edition. With amendments and additions until November 1, 2016) Special part / M. Rustamboev. - T .: Adolat, 2016. - 960 b.

6. Matlyubov B.B. Crime Set: Qualification: Textbook. - T .: Academy of the Ministry of Internal Affairs of the Republic of Uzbekistan, 2009. - 68 p .;

7. Otajonov A.A. Crimes against the person: Textbook. - T .: Academy of the Ministry of Internal Affairs of the Republic of Uzbekistan, 2012. - 294 p. 